\title{
Emotions and Experience in Martin Luther
}

\section{Kärkkäinen, Pekka Antero}

Oxford University Press

2017

Kärkkäinen , P A 2017 , Emotions and Experience in Martin Luther . in D L Nelson, P R Hinlicky, L Malcolm , M L Mattox , R Saarinen, A Vind \& J Zachhuber (eds), The Oxford Encyclopedia of Martin Luther . vol. 1, Oxford Research Encyclopedias, Oxford University Press , Oxford , pp. 436-448 . https://doi.org/10.1093/acrefore/9780199340378.013.353

http://hdl.handle.net/10138/225756

https://doi.org/10.1093/acrefore/9780199340378.013.353

acceptedVersion

Downloaded from Helda, University of Helsinki institutional repository.

This is an electronic reprint of the original article.

This reprint may differ from the original in pagination and typographic detail.

Please cite the original version. 


\title{
Emotions and Experience
}

\author{
Pekka Kärkkäinen
}

This is a draft of an article that has been accepted for publication by Oxford University Press in the Oxford Research Encyclopedia of Religion. Published online in 2016

(http://religion.oxfordre.com/view/10.1093/acrefore/9780199340378.001.0001/acrefore-

9780199340378-e-353).

\section{Summary}

Luther's view of emotions is firmly based on traditional language. He prefers to use affect as a general term for emotional phenomena, which includes general inclinations of love and hate, which involve more incidental emotions such as joy and fear. In general terms, emotions always have a cognitive content, although they are for Luther more than mere cognitions. In some cases, Luther even enjoins a cognitive manipulation of unwanted emotions, using traditional forms of piety such as meditation on Christ's sufferings. In the healing of emotions both in the spiritual and in natural realms, music has a prominent place for Luther. The main cognitive source of spiritual emotions for Luther is the Word of God, dispensed by God himself in the Scripture as the supreme rhetorician. Luther also noted the social nature of emotions. In particular, he appreciated the innate emotional bonds between the members of the family as God's means for securing the wellbeing of humankind. The emotions are so deeply embedded in human nature that all the saints and even Christ himself were not without them. Luther's ideal is not Stoic apatheia, but rather a moderation of emotions. Luther seldom attributes genuine emotions to God. He considers biblical language on God's anger pointing to his future judgment rather than any present state of mind. Luther intimately connects faith, which grasps the promises of the Gospel and creates the certainty of salvation, with human emotional life. This has a double effect on the emotions, providing comfort against the fear caused by sinfulness and external adversities, as well as creating spiritual joy and peace of mind. Fear of God is an ambiguous emotion for Luther. The right kind of fear connected to reverence is essential to Christian life, and a similar fear should be felt for parents and authorities. Faith creates joy which drives away fear, but the remaining sinfulness means that a certain amount of fear remains in this life. Fear and joy are dynamically complementary in Luther's view and he accuses his adversaries of preaching false security, which gets rid of the fear by denying the inherence of sin and mortality in human life. As with emotions, Luther adopts the traditional terminology of experience, but develops it in a creative manner. Experience of God's both negative and positive presence is essential for theology, especially for understanding the true meaning of the Scriptures. However, in comparison to Scripture, experience is insufficient in spiritual matters.

\section{Keywords}

affect, fear, joy, anger, certainty, security, experience, adversities

\section{The Nature of Emotions}


Luther was usually more interested in describing the various internal acts than theorizing about the powers of the soul. This also applies to his view of emotions. It would even be misleading to characterize phenomena like emotions straightforwardly as psychological or mental, since he was writing predominantly in the theological context, and criticized the theological applications of the Aristotelian psychology of his time harshly. However, it is obvious to a reader of Luther's texts that he used traditional terminology to describe the emotional life of human beings, including such terms as appetite (appetitus), affect (affectus) and passion (passio), which were used in medieval philosophy to point out the psychological structures of human and animal souls.

In Luther's medieval predecessors, emotions were conceived as a kind of inner movement. In the medieval view, emotions were usually thought to be acts of appetitive powers of the sensory or intellectual soul. The term appetite was used in the via moderna of Gabriel Biel for a general concept of various inclinations to produce physical or psychological movements. In the area of inanimate objects, every material object has an appetite towards its natural position, such as weight forcing a stone downwards. Such a natural appetite presupposed cognition only in the derived sense of God knowing the laws of nature that produce such an inclination. In contrast to natural appetites, Biel considered the psychological appetites as reactions to various kinds of cognitions. ${ }^{1}$

Biel notes that the more recent translation of Aristotle renders affect (affectus) instead of the passion (passio) of the older translations for the word pathos in the Greek original. However, Biel himself prefers to use affect only for the rational appetite, i.e., the will. ${ }^{2}$ In this respect, Luther largely follows Biel. Luther prefers affectus as a term for describing emotion, but often uses it to mean the will in contrast to the intellect. ${ }^{3}$

However, in his occasional remarks on various topics Luther adopted a wide a wide range of traditional usages of the term, many of which do not have anything to do with what usually is considered as emotion. This is evident in his comment on Biel's distinction between psychological and natural appetite, where Luther, in order to prove a theological point, stretches the meaning of love (understood here as a synonym for appetite) to include the natural inclinations of bodies and states that even they have their (kind of) love in their weight and (a kind of) cognition (notitia) in their figure and measure. ${ }^{4}$ Similarly, Luther occasionally draws from Aristotelian language about inclination or the appetite of matter towards a form. These examples show that Luther includes a strongly ontological aspect in his usage of terms like appetite, which may sometimes be hard to distinguish from emotional and experiential aspects. ${ }^{5}$

Certainly, Luther's focus is not to speculate on what kind of faculties we possess for the emotions since he frequently questions the power of the fallen human being to produce the right direction of the will or affect without grace. Therefore, the affect as a basic inclination of the individual is intimately bound to the status of the human being in relation to God (coram Deo). Basic affects direct the whole person towards God and consequently direct all human actions, including emotional life. These include love and hate above all. ${ }^{6}$ The basic spiritual affect is by nature a continuous activity that relies on the presence of the Word of God. The Word feeds the spiritual affect, so that even during sleep, a Christian continually ruminates on the Word, which produces spiritual emotions. ${ }^{7}$ 
Unlike more clearly emotional phenomena, the basic affects are hidden from direct experience such as introspection according to Luther. ${ }^{8}$ He thus sees them as more a source of emotional phenomena than those phenomena themselves. Despite his various reservations against the traditional ontology of basic affects such as love, in discussing emotions, Luther makes much use of traditional classifications. Both in the Dictata as well as in the mature Preface to the Psalter Luther presents a traditional list of four basic emotions: hope, joy, fear, and grief. Perhaps because of his view of basic affects, he never classifies the basic emotions under the faculties of concupiscible and irascible appetite, as was the case for his predecessors. Nonetheless, occasionally he classifies the four principal emotions under those generated by love of good objects or by hatred of bad objects. ${ }^{9}$ As we saw above, as basic affects love and hate are not faculties for Luther but operations of the soul, although they have a certain permanent nature. Luther comes close here to the terminology used by his teacher Trutfetter, who adopted it from Peter of Ailly's discussion about the passions of the sensory soul. ${ }^{10}$

In his early theology, Luther also adopts the notion of an affective conscience, in which he considers the emotional response so intimately connected to judgment about good and evil that it seems proper to say that the conscience is an instance of both making a moral judgment and initiating action based on that judgment. A similar view is also found in Trutfetter. While Luther strongly developed the terminology of emotions in his theological works, the basis of his language is deeply rooted in the vocabulary of his predecessors. ${ }^{11}$

\section{Components of Emotions}

Since Aristotle and until recent philosophical discussion, emotions have been analyzed as compositions involving distinguishable aspects as follows: (1) a cognitive component, which Aristotle considered as an evaluation regarding something positive or negative happening to the subject or someone related to the subject, (2) a feeling accompanied by the evaluation, (3) a behavioral suggestion towards some action, and (4) a bodily change associated with the emotion. ${ }^{12}$ Luther's discussions of emotions give prominence to the cognitive component, although at least some of the other aspects can be discerned in his comments. ${ }^{13}$

As in earlier theological literature, discussions of the cognitive aspect of emotions are mostly found in Luther's texts concerning the spiritual life. For example, he describes the temptations caused by sin and evil as being mediated alike by sinful mental images and thoughts, which arouse inappropriate emotions. One could expect that Luther's advice for resisting temptation would be mere reliance on the grace of God, given the overall emphasis on the passivity of the individual. However, this is not the case. Luther does not hesitate to adopt a kind of cognitive cure for a sinful emotional life. A similar approach had been widely elaborated by the ascetic tradition since the patristic era and throughout the Middle Ages. As practical advice, Luther advised repetition and meditation on the truths of faith, using imagination, rhetoric and understanding as powerful devices to arouse holy emotions in order to displace the sinful ones. ${ }^{14}$ For instance, Luther may describe in the spirit of traditional passion mysticism how love and admiration are raised when one hears that an innocent person has been murdered. If one hears of the nobility of the person murdered, the sympathy increases even further and the more so finally in that He, namely Christ, was murdered for your sake. ${ }^{15}$ 
Metzger has pointed out that for Luther spiritual emotions follow the cognitive pattern, where knowledge of God's action leads to a specific knowledge of oneself, which in turn generates a corresponding emotional response. ${ }^{16}$ This pattern may be seen in the generation of fear, for example, ${ }^{17}$ It is less clear whether one can see Luther applying the pattern to faith and love, although he likes to consider faith as the cognitive factor, which arouses love as its consequence in the likeness of an emotional response. However, Luther also tends to describe the generation of spiritual love as giving of the Holy Spirit, which does not so neatly fit into a description of faith as a causal principle of love. Indeed, Luther combines both descriptions in a sermon from 1520: "As I hear that Christ is dead on my behalf, and believe, the Holy Spirit will be given to me. The faith arouses love in me, and this love is the Holy Spirit." ${ }^{18}$ The tension between the two descriptions cannot be overstated, since Luther considers the Trinitarian God as intimately present in the life of a believer from the beginning of justification, and uses the terminology of sending rather loosely in the discussion of the Holy Spirit without implying that the Holy Spirit would in any sense be absent before being given in a novel manner. Similarly, the generation of faith and love, even if described in the psychological terminology of cognition and emotion, are theological virtues constantly derived from the presence of the Trinitarian God through the Holy Spirit. ${ }^{19}$

The cognitive origin of spiritual emotions is perhaps more evident in Luther's descriptions of the Word of God as the cause of new emotions in the righteous. ${ }^{20}$ Considering the Word and emotions in Luther opens up a discourse full of metaphorical language from the area of rhetoric. Raising holy emotions requires that the Word of God not remain in barren letters, but become alive in the living, oral preaching of the Gospel. ${ }^{21}$ In oral preaching, people can recognize the primary rhetorician of the Word, God himself. Like a good rhetorician, he can, for example, use the copiousness of words to comfort the fearful soul. ${ }^{22}$

Luther also notes the connections between emotions and particular bodily changes in a traditional manner. In addition to most obvious facial expressions, skin color, bodily temperature and the intestines, particularly the heart, also undergo changes in connection with emotions. The physical expressions are not excluded even from the most spiritual emotions like spiritual joy. This is in line with Luther's overall holistic view of human life. It is evident that Luther does not confine even the most spiritual emotions to a specific part of the individual, since they have relevance to the whole person, including the body. ${ }^{23}$

\section{Emergence of Emotions}

Luther in not unaware of the social nature of emotions. In the spiritual realm, compassion involves a strong social content. ${ }^{24}$ In his late Lectures on Genesis, Luther frequently mentions the emotional bond between family members. Examples of this can be seen in the life of the patriarchs. Some of these cases highlight their basis in the theology of creation: the emotions in the family have a special holy status as something which God has decreed and put into human nature. This applies not only to humans, similar emotions existing in other animals as well. Luther sees the corruption of social emotions through sin and vice as an evil form of heartlessness. ${ }^{25}$

The naturalness of emotions in general seems to be one of Luther's concerns at least in the Lectures on Genesis. For Luther, the word natural is ambiguous: it may refer to the state in which people were created and which existed in paradise, but also to the remnants of that in our current fallen state. The most natural emotion would undoubtedly be for Luther the pure affect of love of 
God, which Adam had before the Fall. In paradise, the first humans had according to Luther no illicit passions and were without fear of death. ${ }^{26}$ Abraham serves for Luther as a comforting example of natural emotions in our fallen state. Although a patriarch, he was as fearful as we are, as appears when he does not dare to reveal that Sarah is his wife. ${ }^{27}$ The most holy patriarch Abraham is not an angel, but a fearful human being. Similarly, even Christ himself felt natural human fear, anger, and sadness, but all this took place without the corruption of sin. Since Christ was like us, but without sin (Hebr. 4:15), his experience shows for Luther that such emotions arise even from uncorrupted human nature, but in a moderated manner and in legitimate use. ${ }^{28}$ Even if Luther in many cases distinguishes between natural and spiritual emotions, there is no fundamental dissimilarity between the two classes. On the contrary, they seem to be at least analogous, and occasionally Luther seems to think that the natural emotions need to be baptized as spiritual emotions, which means bringing them under the moderation of faith. ${ }^{29}$

Certainly, many emotions are caused by original sin and are also counted as sinful. Even believers are not devoid of sinful emotions, retaining the sinful nature which causes them. ${ }^{30}$ Luther adopted Augustine's view of the inevitability of evil emotional impulses, which arise in the individual before the will consents to them in a sinful way. Together with standard medieval doctrine, Luther is ready to admit that the spontaneous impulses for sinning may not themselves be mortal sins, but even without the consent of the will they are indications of our depravity and should be considered as grave sins requiring remorse and forgiveness. ${ }^{31}$

Luther usually depicts the ideal for a Christian emotional life as moderation of emotions. However, he sometimes seems to lean towards a wording that involves a hint of Stoic apatheia, freedom from emotions. In his Commentary on Ecclesiastes (), the goal seems to be the formation of peaceful and quiet souls without cares or lust for future things, which sounds very much like Seneca. ${ }^{32}$ Generally, Luther with Augustine disapproves of the Stoic doctrine of apatheia as a state to be pursued. On the contrary, he considers such an ideal as non-human and a plainly misguided example for the Christian, referring to the examples of David and Mary, who suffered extreme pain and sadness. ${ }^{33}$

Contrary to what one would expect, Luther does not recommend only passivity and receptiveness to the grace of God for Christians in order to attain the ideal emotional state. Especially in his Commentary on Ecclesiastes (1526/32), Luther advises ways of controlling unwanted emotions, in the spirit of a long tradition beginning from the Stoic cognitive therapies. Much of Luther's advice is cognitive in nature, like that which he gives for preparing oneself for adversity: enjoy good things as they happen without fixing oneself too much on the feeling of joy the thing causes in order to reduce the loss of luck; or, when adversity comes, consider it natural or common to people so that it does not feel so severe. ${ }^{34}$ An appropriate contempt for the world leads to a calm and peaceful heart amidst the misfortunes. ${ }^{35}$ Regarding the formation of a sound emotional life, Luther also believes in education according to good sense and good opinions, and avoiding the influence of bad company. ${ }^{36}$

Among the diverse disciplines, Luther characterizes the art of rhetoric as the task of raising emotions, although it needs logic (dialectica) for gaining reliable and clear knowledge about the subject matter. ${ }^{37}$ Although the truth of the discourse was of primary importance for Luther, he did also consider the ethos of the speaker as an important factor. The preacher must be fearless and bold against any worldly dangers. ${ }^{38}$ Luther describes the sermon of the apostles at Pentecost as an 
archetype of such bold preaching and as such also as an example of the miraculous presence of the Holy Spirit, since bold preaching in front of all the people was beyond their natural capacities as simple fishermen. ${ }^{39}$

In addition to rhetoric, Luther considers music another art which is particularly devoted to raising emotions. Music serves particularly well for redirecting unwanted emotions. In his Encomion musices (1530) Luther praises music as something which directly touches the emotional center of the individual, the heart. Music even has the capacity to arouse emotions without resorting to cognitive content, although it does often contribute to the deepening of cognitively raised emotions. Luther was ready to accredit music with the ability to enhance the power of the words in the service of spoken Word of the Gospel, but music also directs the emotions independently of the cognitive content. The most precious effect of music is for Luther that it creates delight or joy among the hearers that is not tainted by evil desires like other sensuous delights. The delight it causes is innocent, which makes music a special gift of God. This is for Luther a basis of music as an instrument of healing, since it drives sadness away, as was the case in the story of David at the court of Saul (1. Sam. 16:23). In discussing music, Luther does not make a sharp distinction between emotions in the natural and spiritual realms, but highlights the contribution of music in the service of the Gospel. ${ }^{40}$

Finally, spiritual emotions are raised in the reading of and meditation on Christ's passion. A considerable part of Luther's early discussions of spiritual trials (Anfechtungen) in the Dictata arise from the idea of a Christian sharing Christ's sufferings, which are highly emotional in character. This includes joining Christ in the descent into Hell through meditation. The descent is not corporeal, but a spiritual descent in affect (affectualis). By acknowledging one's culpability, which Christ's suffering brings to the fore, one joins the fear of the damned in Hell. However, Christ's descent also brings the contrary emotions of hope and love because of his resurrection and victory over death and Hell. ${ }^{41}$

Luther's use of emotional terms like anger and love for describing God has also attracted some interest. Despite the relatively great importance of God's wrath, Luther ultimately conceived God as a loving Father. On God's love, see >Love. Pinomaa comes to the conclusion that the view of God's anger is not destructive for Luther's view of God as an ultimately loving Father. His main argument is that God's anger arises as a reaction to human sinfulness, and for Luther God is a loving Father even towards sinners. ${ }^{42}$ Pinomaa points out the connections between God's anger and human experience and emotions, especially fear. Fundamental for God's anger is the idea of divine judgment which, together with the knowledge of one's sinfulness, causes diverse fears and anxieties: fear of eternal damnation, and anxiety (Anfechtung) about one's predestination based on the experience of God's anger. ${ }^{43}$

At least once in the late Lectures on Genesis Luther addresses the problem of attributing emotional terminology to God, which seems to contradict divine properties. The remark in Gen. 6:5-6 about God repenting that he had created humankind, seems to contradict his eternal prescience and predestination. In this case, Luther is reluctant to attribute the repentance to God in his divine majesty, but solves the problem pneumatologically in that one can say that God repented, but it actually means that the Patriarchs, such as Noah, in whom the Holy Spirit inhered and were at the service of the Word, were the ones who repented. The Holy Spirit as God in his proper nature remains unaffected by human depravity, but the Holy Spirit qua residing in Noah's 
heart is said to repent, because of his office of serving the Word in mankind. This example shows that Luther was not willing to take the anthropomorphic language of the Bible, including emotions attributed to God, at face value. ${ }^{44}$

\section{Faith and Emotions}

It is typical of Luther to locate central concepts such as faith semantically using concepts with emotional connotations. Faith is for him a cognition with an emotional cast, knowledge of the heart. In the Dictata, Luther highlights the character of faith vis-à-vis natural knowledge, describing faith as a kind of higher intellect capable of grasping truths about the invisible world, but also as a kind of affective and experiential knowledge that extends beyond theoretical knowledge. ${ }^{45}$ Therefore, the frequently cited statement from the Dictata: "Faith does not enlighten the understanding, indeed, it blinds it, but rather the heart (affectum)" ${ }^{46}$ by no means represents the whole story, since Luther also sees faith a form of spiritual understanding. In his early works, in which the emotional character of faith takes a prominent role, Luther shows clear similarities with the experiential mysticism of Bernard of Clairvaux. ${ }^{47}$

In the Resolutions to the Theses against Indulgences (1518) Luther anchors the concept of faith in experience and emotions with the concept of certainty. Faith grasps the promises of God in the Word of the Gospel and is hence derived from reality, which is undeniably external to the human being. This external aspect guards against an overly subjective focus on one's internal emotional life and links faith to the objective truths of the revelation. However, there is at the same time necessarily a subjective aspect in faith, which has a profound impact on the emotional life of the believer. The certainty inherent in faith generates trust in God, the experience of joy, together with peace of mind and consolation. These new emotions together drive away the fear caused by the demands of the law and anxiety about one's predestination. In the Bondage of the Will, Luther explains how certainty of faith can guard against anxiety about predestination. The reason for this is that the certainty of faith implies a consciousness of God's sole efficacy in his action of grace, and therefore leads the focus away from one's own efforts and internal states. ${ }^{48}$

Although certainty of faith may contain an emotional component in itself, it is important for Luther that certainty only creates an emotional response, and is not caused by the experience of emotion. The external Word and God's grace are sufficient for creating faith, through the awareness of which one is able to be certain that the promises apply to oneself. The reflexive nature of faith itself is therefore the basis of its certainty and, since it is based on the external Word of promise, it also prevails in the midst of contrary experiences of adversity, sin and fear. ${ }^{49}$

Throughout his works Luther reflects on security, another concept closely related to certainty. In contrast to certainty, Luther considers security in negative terms, often adding the attribute "false" to it. Luther develops his early attacks on false security in the Dictata and in Lectures on Romans. In contrast to certainty, the main problem in security being the denial of the human condition as radically sinful and the consequent lack of a justified fear of God. The lack of fear of God leads to spiritual pride, when God's judgment is seen as applicable to others but not to oneself. Luther considers it good that God occasionally lets a person yield to temptation, which causes fear before God and drives away false security. Security therefore has a different bearing on fear and adversity than certainty: whereas certainty drives away the fear caused by sin and adversity, security is caused by the absence of legitimate fear and adversity. For Luther, the right 
order of emotional fear and peace is essential, together with the dynamic coexistence of the right kind of fear of God and certainty. ${ }^{50}$

Thus in relation to emotions, both certainty and security seem to have a similar effect in that they drive away fear and bring internal peace. However, in addition to their ordering as regards fear, Luther also describes another essential difference between them in relation to emotions. He elaborates this in his late disputations against the Antinomians. According to Luther, the false security of the Antinomians is caused by the teaching that Christ is identified as sweet security. According to Luther, sweet security constitutes for the Antinomians an emotional basis for a false kind of certainty, contrary to the necessary external basis for true certainty, which is not dependent of the experience of sweetness. This is reaffirmed by his statements that this false kind of security does not prevail in facing adversities such as death or a bad conscience. Here Luther develops ideas already present in his Dictata and Lectures on Romans. As in the early work, the fatal error in this kind of security is for Luther that it is based on the denial of the human predicament of mortality. Consequently, such security replaces a salutary fear of God, which is also a necessary precondition for genuine faith. ${ }^{51}$

\section{Complementarity of Fear and Joy}

As has already been hinted above, the emotion of fear has a prominent role in Luther's thinking. As Thorsten Dietz has shown, its role even changed somewhat over the years. In the Dictata, Luther focused on the distinction between servile and filial fear of God. This distinction served in arguments against the gradualist soteriology of the Middle Ages, since the right kind of fear drives the individual to the affirmation of utter helplessness and search for grace, but not all fear is of that kind. Luther discards the positive function of a servile fear, a fear of temporal punishment. In the tradition, it could serve as a pedagogical means for advancing in more spiritual motivation. For Luther, fear of temporal punishment can only cause reliance on one's own merits or lead to desperation and hating God. Nevertheless, Luther accredits another related kind of fear, the fear of Hell. The decisive point in servile fear is that it involves temporal punishment, whereas fear of Hell or Final Judgment is directed to eternal punishment. This aspect annuls all human effort based on self-love. Thus, for Luther the right kind of fear does not lead to a higher level of spiritual life as it did in the medieval soteriological theories, but essentially destroys the false strivings of the sinful self. ${ }^{52}$

Following the traditional lines, Luther considers the most proper kind of fear as filial fear, which is connected with the right kind of love, love of God. ${ }^{53}$ Such a fear can co-exist with true joy, which Luther describes as a characteristic emotion of a spiritual individual. He explicitly connects joy to faith and considers it as based on God's promises. Furthermore, Luther describes spiritual joy as independent of life's external course and implies a fearlessness regarding external misfortunes. The compatibility of the right kind of fear with spiritual joy and peace the basis for developing a unified view regarding these two emotions remains in Luther's thought, despite the incidental need to accentuate their dialectical opposition. ${ }^{54}$

Analysis of fear and adversity during the time of the Dictata provided Luther with the context for overturning traditional soteriological schemes. Nearer to the time of the Resolutions, Luther's focus moved to consider fear and joy in antithetical terms, where joy was associated with the internal peace brought by the certainty of faith, driving fear away. During the early 1520 s, this 
notion developed in connection with the idea of God's law as the basis of fear and even hatred of God in natural person. In relating fear with the emotion of hatred, Luther explicitly joined some sayings of Jerome. ${ }^{55}$ In other works of this time, Luther also shows signs of relativizing the juxtaposition between fear caused by the law and joy caused by the Gospel. In the Operationes, he mentions that the law can drive one to utter fear of God's wrath even in the presence of faith. ${ }^{56}$ Despite this, during the 1520s Luther describes the juxtaposition of fear and joy in a way that suggests a diachronic reading of the relationship between these emotions in a person: first, law frightens one because of sin, but then the Gospel brings comfort and joy with the promise of forgiveness. Despite the systematic problems of not considering the legitimate fear of God, such a reading has a certain didactic and pastoral plausibility in the preaching of the Gospel.

Another strain in Luther's thought about fear is the analogy between fear of parents and fear of God, as Luther presents it in his commentary on the Decalogue in On Good Works (1520). In both cases, the ideal kind of fear appears as reverence, which is a form of fear combined with love. This reminds one of the concept of the filial fear of Luther's early writings. The different ways of interpreting the right kind of fear leave some tensions in Luther's terminology during the early 1520s unresolved. ${ }^{57}$

After their experiences during the Saxon visitations in 1527, the dialectic of law and the Gospel was sharpened in a new way in both Luther and Melanchthon. At the same time, Luther faced the personal fear of death in a novel way because of the epidemic of the plague and his own health problems. More consciously than before, Luther considered law and the Gospel as entities, which simultaneously address people even as believers. Whereas the Gospel consoles the heart of a new person in Christ with forgiveness of sin, the law still continues to frighten the old self because of the remaining sinfulness. In addition to an obvious diachronic reading of the contrariety between fear and joy, Luther now formulates an explicitly synchronic view of these contrary. Such a view may be considered as an application of Luther's view of the continuous struggle between flesh and spirit or man as simul iustus et peccator discussed since his early writings. Consequently, the emotional life of the Christian appears as a continuous struggle between fear and joy, giving it a strongly dynamic aspect. ${ }^{58}$

In the Catechisms, Luther applies the synchronic principle to the interpretation of the First Commandment. The commandment requires us to both fear and love God, which now for Luther includes genuine fear in addition to love in the believers, who can fulfil the demand of the commandment through the Holy Spirit. In addition to the love filled with due reverence for God, the believers are called to fear God for their remaining sins, which is often revealed to them in confronting the state of their own mortality. Forgetting this is one of Luther's accusations against the Antinomians, and Luther continues to apply the whole spectrum of the concept of fear in his description of the righteous during the 1530s, even including the aspect of horror. ${ }^{59}$

\section{Experience}

From the preceding discussion about emotions, it should be obvious that Luther's theology contains a strongly experiential element. This not only applies to his style, but is also articulated in his view of theology. In addition to this, Luther has also reflected on the concept of experience in several senses of the term, drawing from the rich tradition of western thought. In Luther's context, the term experientia had several uses, which had more or less epistemological connotations. In 
the Aristotelian philosophical tradition, experience meant either (1) knowledge based on sense perception or (2) introspection, but also, derived from the former, (3) knowledge gained through practical activity in contrast with speculative knowledge. All three senses were elaborated in the medieval discussions, not least among the theological writers, especially in various contexts of the mystical tradition. For Luther, one particularly important source of thought was Bernard of Clairvaux. $^{60}$

The peculiar character of Luther's theology of experience becomes evident in comparison with the previous mystical tradition. Luther was against a kind of elitist mysticism that cherishes ecstatic and other kinds of extraordinary experiences. ${ }^{61}$ At the same time, he retained the mystical terminology of an immediate experiential encounter with divinity, although replacing soul and God with faith and the Word. ${ }^{62}$ The experience is, however, characteristically marked with adversities (Anfechtungen). Drawing from passion mysticism and Tauler, Luther considers identification with Christ's sufferings and the experience of spiritual annihilation as an essential part of the Christian life. ${ }^{63}$ In the description of the experiential encounter with God, Luther distances himself from Tauler by accentuating the experience of God's present and personal anger. The experience of God's majestic presence appears in the negative form of a frightening God, which calls for finding consolation in God's mercy. ${ }^{64}$

Luther sternly warns against considering experience as the only source of theological knowledge in loose agreement with the medieval principle, which considers experience as deceptive (experimentum fallax). ${ }^{65}$ Luther often considers experience as deficient in comparison to the faith based on Scriptural testimony. His intention is not to undermine the relevance of experience, but to highlight the importance of revelation. The truths of faith are more certain than those derived from experience and some of them are about things that are simply not accessible to experience. $^{66}$

However, apart from Scripture, experience excels as the most central source of theological knowledge. In the Dictata Luther refers to adversity as a test of faith. Through adversity, the genuineness of faith and theology can be tested and only someone who has experienced adversity gains the kind of experiential knowledge required of a true Christian and a good theologian. Similar notions are not absent from Luther's later theology. ${ }^{67}$

In this usage, experience often appears as knowledge based on practice in contrast with theoretical knowledge, or as emotionally colored knowledge of the heart in contrast with the merely cognitive knowledge of faith. As for the anthropological location of experience, in addition to the heart Luther often mentions conscience. ${ }^{68}$ The total contribution of experience in spiritual matters comprehends a combination of both negative and positive experiences, internal and external adversities being supplemented by a positive experience of faith. The internal experience of faith and its consequences like certainty and positive emotions like joy enable Christians to obtain consolation and endure adversity (see above).

Similarly, experience serves as a source of knowledge in the hermeneutic sense. Luther often calls for a testimony of experience as a confirmation of the Scriptures, but not only as mere confirmation, but as a means of understanding the true meaning of the Scriptures. As a hermeneutic tool, experience draws not only from adversity or the internal experience of faith, but many everyday experiences as they are available in proverbial wisdom. Things like the 
impossibility of chastity or the success of the godless belong to such every day experiences, which both Christian and non-Christian writers confirm as common knowledge according to Luther. ${ }^{69}$

Luther can truly be considered as a theologian of experience. While being aware of the shortcomings of experience in the spiritual realm, his view includes a conscious reorientation to the experiential nature of Christian faith. The enhanced awareness of a negative experience of God and correspondingly even more intensified awareness of God's grace lead Luther to deem experience as indispensable. For him, this not applied only to the life of an individual, but above all to interpretation of the Scriptures and consequently to theology.

\section{Review of Literature}

In 1964, Günther Metzger published a monograph on Luther's discussions on emotions and experience, ${ }^{70}$ focusing on the Dictata, which provide a rich source for Luther's views on emotions. As an early work, it gives a glimpse into a particular phase in the evolution of Luther's thought, and many issues discussed there reappear in Luther's later oeuvre. Metzger reflects on the semantic questions of Luther's terminology of emotions, but his main contribution consists of analyzing Luther's sayings in the context of a Christological and more broadly theological context.

Another early contribution to the research came in the form of articles by Karl-Heinz zur Mühlen. ${ }^{71}$ As in Metzger, the focus in zur Mühlen's analysis concentrates on the early Luther, but not exclusively. Zur Mühlen also extends the discussion of Luther's relationship to the preceding theories of emotions, trying to articulate the new aspects in Luther's reformatory approach concerning the emotions.

In an unpublished licentiate thesis from 2005, Antti Elenius pursues an overall picture of Luther's view of emotions based on his writings from different periods. In particular, Elenius engages in analyzing Luther's views from the viewpoint of a componential view of emotions, which differentiates between cognitive, affectual, and physical aspects. This enables him to posit Luther more reliably among the tradition of theories of emotions, although the Reformer does not have much to say of all its aspects. Elenius's study shows, however, the broad range of contexts and ideas included in Luther's sayings about emotions, which underlines the importance of the language of emotions for several areas of Luther's theology, including observations on lessdiscussed natural emotions.

Elenius's findings are complemented by Miikka Anttila's analysis ${ }^{72}$ as a part of his study on Luther's theology of music. In reference to Elenius, Anttila contends that Luther's view of the emotions aroused by music eludes the componential analysis of emotions, since music is able to cause and direct emotional responses in feelings without specific cognitive content. Anttila highlights Luther's sayings, which accord music a primary role in manipulating human emotions, and shows the many ways in which Luther sees music raising various kinds of emotion from simple secular delight to spiritual joy connected with faith.

Among the recent contributions, Thorsten Dietz provides a thorough study on the emotion of fear in Luther's theology. ${ }^{73}$ His sources range through all periods of Luther's life, and further into our times by linking Luther's insights with modern discussions on the management of fear in pastoral theology. Unlike earlier studies, Dietz is able to trace particular changes in Luther's concept of 
fear, although the matters discussed remain the same to a surprising degree. Whereas Elenius's study had affirmed the general significance of emotions for Luther's theology, Dietz's example shows that there is much to learn about Luther's scattered sayings if one concentrates on one particular emotion.

As a whole, the studies show that Luther used the terminology of emotions in a way that was both traditional and innovative. At the same time, it is obvious that the full potential of the question of Luther and emotion has hardly been exhausted. The terminology of the emotions reappears at crucial points of Luther's theology, particularly in the context of justification, so that one could perhaps trace an express recourse to emotion terminology in, how Luther rephrases the spiritual life of the Christian. Furthermore, the specific ways in which Luther's terminological innovations relate to the late medieval tradition, particularly the writers of the mystical tradition, has yet to be more carefully scrutinized.

\section{Further reading}

Miikka E. Anttila, Luther's Theology of Music: Spiritual Beauty and Pleasure, (Berlin: de Gruyter, 2013).

Albrecht Beutel, "Theologie als Erfahrungswissenschaft" in Luther Handbuch edited by Albrecht Beutel (Tübingen: Mohr Siebeck, 2005), 454-459.

Thorsten Dietz, Der Begriff der Furcht bei Luther, (Tübingen: Mohr Siebeck, 2009). Günther Metzger, Gelebter Glaube: Die Formierung reformatorischen Denkens in Luthers erster Psalmenvorlesung dargestellt am Begriff des Affekts, (Göttingen: Vandenhoeck \& Ruprecht, 1964). Karlheinz zur Mühlen, "Affekt II. Theologiegeschichtliche Aspekte" in Theologische Realenzyklopädie 1 (1977), 599-612.

\section{Notes}

${ }^{1}$ Leif Grane, Contra Gabrielem: Luthers Auseinandersetzung mit Gabriel Biel in der Disputatio Contra Scholasticam Theologiam 1517, (København: Gyldendal, 1962), 98-107.

${ }^{2}$ Detlef Metz, Gabriel Biel und die Mystik, (Stuttgart: Franz Steiner), 83-4.

${ }^{3}$ Karlheinz zur Mühlen, "Affekt II. Theologiegeschichtliche Aspekte" in Theologische Realenzyklopädie 1 (1977), 606-607.

${ }^{4}$ WA 59, 41, 25-29.

${ }^{5}$ cf. Miikka E. Anttila, Luther's Theology of Music: Spiritual Beauty and Pleasure, (Berlin: de Gruyter, 2013), 110-111.

${ }^{6}$ Günther Metzger, Gelebter Glaube: Die Formierung reformatorischen Denkens in Luthers erster Psalmenvorlesung dargestellt am Begriff des Affekts, (Göttingen: Vandenhoeck \& Ruprecht, 1964), 71; 79; 135; Thorsten Dietz, Der Begriff der Furcht bei Luther, (Tübingen: Mohr Siebeck, 2009), 8384.

${ }^{7}$ Antti Elenius, Lutherin käsitys tunteista [Luther's View of the Emotions], Unpublished Licenciate Thesis (University of Helsinki, 2005), 116-7.

${ }^{8}$ Anttila, Luther's Theology of Music, 113.

${ }^{9}$ Anttila, Luther's Theology of Music, 114; Elenius, Lutherin käsitys tunteista, 58-60.

${ }^{10}$ Jodocus Trutfetter, Summa in totam physicen, (Erfurt, 1514), Gg4v; Peter of Ailly, Tractatus de anima, ed. Olaf Pluta in Die philosophische Psychologie des Peter von Ailly, (Amsterdam: B.R. Grüner, 1987), 90. 
${ }^{11}$ Metzger, Gelebter Glaube, 146; Kärkkäinen, "Synderesis in Late Medieval Philosophy and the Wittenberg Reformers" British Journal for the History of Philosophy 20 (2012), 881-901.

${ }^{12}$ Simo Knuuttila, Emotions in Ancient and Medieval Philosophy, (Oxford: Clarendon, 2004), 32-33.

${ }^{13}$ Elenius, Lutherin käsitys tunteista, 25-50.

${ }^{14}$ Elenius, Lutherin käsitys tunteista, 35-37.

${ }^{15}$ WA 1, 343, 36-344, 2; Elenius, Lutherin käsitys tunteista, 34.

${ }^{16}$ Metzger, Gelebter Glaube, 198.

${ }^{17}$ Dietz, Der Begriff der Furcht, 245.

${ }^{18}$ WA 9, 463, 14, translation by Pekka Kärkkäinen.

${ }^{19}$ LW 36:40-41 (WA 6, 515, 29-516, 2); Elenius, Lutherin käsitys tunteista, 96; Pekka Kärkkäinen, Luthers trinitarische Theologie des Heiligen Geistes (Mainz: Philipp von Zabern, 2005), 148.

${ }^{20}$ WA 30 1, 146, 31-37; Elenius, Lutherin käsitys tunteista, 114.

${ }^{21}$ WA 101 2, 48, 1-15; 12, 259, 10-13; Elenius, Lutherin käsitys tunteista, 115; Theo Bell, Divus Bernhardus. Bernhard von Clairvaux in Martin Luthers Schriften, (Mainz: Philipp von Zabern, 1993), 1-17, 54-7; Metzger, Gelebter Glaube, 160-171.

${ }^{22}$ LW 2:145 (WA 42, 364, 6-18); cit. Elenius, Lutherin käsitys tunteista, 120.

${ }^{23}$ LW 12:81 (WA 40 2, 295, 27-31); Elenius, Lutherin käsitys tunteista, 42-43; 91.

${ }^{24}$ WA 1, 336, 22-25; Elenius, Lutherin käsitys tunteista, 67.

${ }^{25}$ LW 4:38-40; 111-112; 6:16-17; 7:261; 8:16 (WA 43, 163, 11-164, 7; 215, 20 -216, 3; 44, 11, 18 $12,4 ; 493,3-15 ; 590,37-40)$.

${ }^{26}$ LW 1:62 (WA 42, 46, 16-27); Elenius, Lutherin käsitys tunteista, 93.

${ }^{27}$ LW 3:319-320 (WA 43, 104, 29-36); Elenius, Lutherin käsitys tunteista, 99.

${ }^{28}$ LW 7:262 (WA 44, 493, 32-38); Elenius, Lutherin käsitys tunteista, 113.

${ }^{29}$ LW 11: 508-509; 2:331 (WA 4, 373, 15-28; 42, 498, 37-38); Elenius, Lutherin käsitys tunteista, $100-1 ; 103$.

${ }^{30}$ LW 3:333 (WA 43, 114, 12-18).

${ }^{31}$ LW 21:88-89 (WA 32, 373, 8-29); Elenius, Lutherin käsitys tunteista, 48-49.

${ }^{32}$ LW 15:7; 13:81 (WA 20, 9, 31-10, 17; 40 2, 295, 27-31); Elenius, Lutherin käsitys tunteista, 70.

${ }^{33}$ LW 15:127; 27:81; 7:315 (WA 20, 146, 34-35; 40 2, 102, 17-103, 11; 44, 533, 16-20); Elenius, Lutherin käsitys tunteista, 66; 73; Anttila, Luther's Theology of Music, 115-116.

${ }^{34}$ LW 15:160-161 (WA 20, 171, 36-172, 25); Elenius, Lutherin käsitys tunteista, 74-75.

${ }^{35}$ LW 15:176 (WA 20, 190, 18-20); Elenius, Lutherin käsitys tunteista, 77.

${ }^{36}$ LW 15:177 (WA 20, 190, 35-37); Elenius, Lutherin käsitys tunteista, 76.

${ }^{37}$ LW 27:24 (WA 40 2, 28, 15-18); Elenius, Lutherin käsitys tunteista, 82.

${ }^{38}$ WA 101 2, 204, 27-29; Elenius, Lutherin käsitys tunteista, 84.

${ }^{39}$ Kärkkäinen, Luthers, 175; 179.

${ }^{40}$ WA 50, 371, 5-9; Anttila, Luther's Theology of Music, 117-124.

${ }^{41}$ Metzger, Gelebter Glaube, 170.

${ }^{42}$ Lennart Pinomaa, Der Zorn Gottes in der Theologie Luthers (Helsinki, 1938), 202.

${ }^{43}$ Pinomaa, Der Zorn Gottes. See also Dietz, Der Begriff der Furcht, 103-107.

${ }^{44}$ Kärkkäinen, Luthers, 161-162.

${ }^{45}$ Metzger, Gelebter Glaube, 112-113; 115-119.

${ }^{46}$ LW 11:485 (WA 4, 356, 23-24); Elenius, Lutherin käsitys tunteista, 106-107.

${ }^{47}$ Elenius, Lutherin käsitys tunteista, 106-114.

${ }^{48}$ Dietz, Der Begriff der Furcht, 245; 247.

${ }^{49}$ Dietz, Der Begriff der Furcht, 249-250. 
${ }^{50}$ Dietz, Der Begriff der Furcht, 92-98; 131-132.

${ }^{51}$ Dietz, Der Begriff der Furcht, 323-325.

52 Dietz, Der Begriff der Furcht, 124-125.

${ }^{53}$ Dietz, Der Begriff der Furcht, 84-85.

${ }^{54}$ Metzger, Gelebter Glaube, 195-6.

${ }^{55}$ Dietz, Der Begriff der Furcht, 253; 259.

${ }^{56}$ Dietz, Der Begriff der Furcht, 254-255.

${ }^{57}$ Dietz, Der Begriff der Furcht, 255-256.

58 Dietz, Der Begriff der Furcht, 275-88.

${ }^{59}$ Dietz, Der Begriff der Furcht, 294, 292-293; 296.

${ }^{60}$ Köpf "Erfahrung III/1. Mittelalter und Reformationszeit" in Theologische Realenzyklopädie 10 (1982), 110; 114; Metzger, Gelebter Glaube, 161; Metz, Gabriel Biel, 81-82 (on Gabriel Biel).

${ }^{61}$ Berndt Hamm, "Wie mystisch war der Glaube Luthers?" in Gottes Nähe unmittelbar erfahren ed. Berndt Hamm \& Volker Leppin (Tübingen: Mohr Siebeck, 2007), 245.

${ }^{62}$ Hamm "Wie mystisch", 264-5.

${ }^{63}$ Hamm "Wie mystisch", 276-82.

${ }^{64}$ Hamm "Wie mystisch", 282.

${ }^{65}$ Köpf, "Erfahrung", 111.

${ }^{66}$ Köpf, "Erfahrung”, 114.

${ }^{67}$ Köpf, "Erfahrung", 114.

${ }^{68}$ Köpf, "Erfahrung”, 114-115.

${ }^{69}$ Albrecht Beutel, "Theologie als Erfahrungswissenschaft" in Luther Handbuch edited by Albrecht Beutel (Tübingen: Mohr Siebeck, 2005), 455.

${ }^{70}$ Metzger, Gelebter Glaube.

${ }^{71}$ zur Mühlen, "Affekt".

${ }^{72}$ Anttila, Luther's Theology of Music.

${ }^{73}$ Dietz, Der Begriff der Furcht. 